\title{
Analisis Faktor Pemekaran Nagari Persiapan Batahan Utara Kecamatan Ranah Batahan Kabupaten Pasaman Barat
}

\author{
Shahira Desiamanda ${ }^{1}$, Tengku Rika Valentina ${ }^{2}$, Dewi Anggraini ${ }^{3}$ \\ ${ }^{1}$ Jurusan Ilmu Politik, Fisip, Universitas Andalas, desiamandashahira@gmail.com \\ ${ }^{2}$ Jurusan Ilmu Politik, Fisip, Universitas Andalas \\ ${ }^{3}$ Jurusan Ilmu Politik, Fisip, Universitas Andalas
}

\begin{abstract}
Abstrak
Penelitian ini membahas faktor pemakaran Nagari Persiapan Batahan Utara. Proses pemekaran nagari dimulai sejak Tahun 2006 dan terealisasikan Tahun 2016 akibat kendala regulasi, penolakan dari walinagari, dan penetapan batas wilayah. Penelitian ini bertujuan untuk menjelaskan faktor yang melatarbelakangi proses Nagari Persiapan Batahan Utara melakukan pemekaran. Penelitian ini menggunakan metode kualitatif dengan studi kasus intrinsik. Teori yang digunakan dari Fitria Fitrani, Bert Hofman, dan Kai Kaiser yaitu faktor sosial, ekonomi, dan politik. Hasil dari penelitian ini bahwa faktor sosial, ekonomi, dan politik saling bersinergitas mendorong Nagari Persiapan Batahan Utara memekarkan diri. Nagari Persiapan Batahan Utara ingin mekar dilaterbelakangi oleh faktor sosial yaitu jasa layanan yang diterima tidak efektif akibat kualitas infrastruktur yang buruk terutama akses jalan hanya tanah sepanjang $7 \mathrm{~km}$, ongkos perjalanan Rp.50.000, jumlah penduduk yang padat terdiri dari 2.598 jiwa, sarana-prasarana seperti komputer dan leptop hanya 7 buah dengan kualitas internet tidak mendukung. Faktor ekonomi yaitu jumlah dana desa yang diterima hanya Rp. 1.131.517,744.00 dialokasikan terhadap 26 jorong, pendapatan asli nagari (PAN) kosong mengakibatkan Nagari Persiapan Batahan Utara hanya mendapatkan 3 kali bantuan pembangunan yaitu jalan beton, bangunan taman kanak-kanak, dan bronjong sungai. Faktor politik ide pemekaran diprakarsai oleh pemerintah daerah dan masyarakat.
\end{abstract}

Kata Kunci: Pemekaran, Proses, Faktor Pemekaran Nagari Persiapan Batahan Utara

\begin{abstract}
This research discusses about the factors of the expansion of Nagari Persiapan Batahan Utara. The process of expanding the Nagari began in 2006 and was realized in 2016 due to regulatory constraints, refusal from the mayor, and the determination of territorial boundaries. The research aims to explain the factors behind the process of Nagari Persiapan Batahan Utara to expand. And then the research uses a qualitative method with an intrinsic case study. The theory used by Fitria Fitrani, Bret Hoffman, and Kai Kaiser about social, economic, and political factors. The result of this research is that social, economic, and political factors that are synergize with each other to encourage Nagari Persiapan Batahan Utara to split up. The expansion of Nagari Persiapan Batahan Utara motivated by social factors, that is the services received are ineffective due to poor infrastructure quality, especially road access, the travel costs RP. 50,000, only for $7 \mathrm{~km}$. The population consisting of 2,598 people, and only has 7 computers and laptops with not supporting internet quality. Then, the economic factors, that is the amount of village funds received is only RP. 1,131,517,744.00 allocated to 26 gearing, the original income of the nagari pendapatan asli nagari (PAN) was nothing, so in the Nagari Persiapan Batahan Utara only getting 3 times development assistance, that is concrete roads, kindergarten buildings, and river gabions. The last is the political factor of the idea of expansion was initiated by the local government and the community.
\end{abstract}

Keywords : Expansion; Process; Factor of expansion Nagari Persiapan Batahan Utara 


\section{PENDAHULUAN}

Konsep Pemekaran lahir dimulai pasca runtuhnya pemerintahan Presiden Soeharto. Kemudian dilanjutkan oleh Presiden Susilo Bambang Yudhoyono pada periode (2004-2014), Selanjutnya masa pemerintahan Joko Widodo-Jusuf Kalla periode (2014-2019) yang dikenal dengan konsep Nawacita. Sembilan point utama dari Nawacita yang salah satunya membangun Indonesia dari pinggiran dengan memperkuat daerah-daerah dan desa dalam kerangka negara kesatuan. Adanya perhatian terhadap desa dilandasi oleh sekitar $65 \%$ penduduk Indonesia bermukim di pedesaan, sisanya sekitar $35 \%$ populasinya berada di perkotaan. Selain itu, dilihat angka penduduk miskin pedesaan berjumlah $24,79 \%$ pada September Tahun 2019. ${ }^{1}$ Dengan besarnya kuantitas jumlah persebaran penduduk di pedesaan dan tingginya angka kemiskinan, maka pemekaran desa menjadi salah satu solusi untuk menjangkau masyarakat yang jauh dari pusat pemerintahan.

Konsep pemekaran lahir atas dasar maklumat dari otonomi daerah. Hasil produk era reformasi yaitu pemekaran juga menghasilkan perubahan secara signifikan dalam model dan paradigmanya dalam pemerintahan. Model efisiensi struktural yang menekankan pada efisiensi dan keseragaman pemerintah lokal mulai ditinggalkan. Selanjutnya beralih terhadap demokrasi lokal yang menekankan nilai demokrasi dan keberagaman dalam model penyelenggaraan pemerintahan lokal. Seiring dengan pergeseran model tersebut berubah dari aspek dekosentrasi kepada aspek desentralisasi sesuai dengan Undang-Undang No. 23 Tahun 2014 tentang Pemerintahan Daerah . ${ }^{2}$ Pemekaran wilayah merupakan upaya pemandirian bagi wilayah tertentu melalui peningkatan kedudukan, baik status maupun perannya dalam administrasi pemerintah, dengan pengertian tersebut pemekaran wilayah berarti pemberian tanggung jawab pengelolaan oleh pemerintah dan pembangunan yang lebih besar, sehingga pada akhirnya masing-masing wilayah akan berkembang dalam suatu ikatan negara dan laju pembagunan pada semua wilayah akan semakin menjadi seimbang dan serasi. ${ }^{3}$

Terbukanya kran pemekaran desa didasarkan pada Pasal 7 ayat 4 Undang-Undang No. 6 Tahun 2014 tentang Desa yang berisi penataan desa yang dimaksud adalah adanya pembentukan, penghapusan, penggabungan, perubahan status, dan penetapan desa. Landasan pemekaran desa selanjutnya berdasarkan Pasal 6 ayat 2 Peraturan Menteri dalam Negeri Republik Indonesia No. 1 Tahun 2017 tentang Penataan Desa menjelaskan pembentukan desa sebagai tindakan mengadakan desa diluar desa yang ada tentunya memiliki pertimbangan prakarsa masyarakat desa, asal-usul, adat-istiadat, kondisi sosial budaya masyarakat desa, serta kemampuan dan potensi desa. ${ }^{4}$

\footnotetext{
${ }^{1}$ Husaen Abdul Salam. 2019. Saat Banyak Kelurahan Ingin Menjadi Desa Demi Mendapatkan Dana Desa, diakses dari Https://www.bps.go.id diakses pada tanggal 13 Juli 2020 pukul 20:00 WIB.

${ }^{2}$ Siregar, Doli D. 2004. Manajemen Aset. Jakarta: Gramedia Pustaka Utama, hlm 255.

${ }^{3}$ Budi Mulyadi \& Ulung Pribadi. 2015. Analisis Persiapan Dalam Perencanaan Pemekaran Desa di Kabupaten Bulungan. Jurnal Ilmu Pemerintahan dan Kebijakan Publik. hlm. 6.

${ }^{4}$ Peraturan Menteri Dalam Negeri Pemerintah Indonesia No.1 Tahun 2017 tentang Penataan Desa.
} 
Terdapat alasan dibalik semakin maraknya pemekaran desa, menurut tim peneliti dari World Bank, faktor yang mempengaruhi adalah: Pertama, motif untuk efektivitas dan efisiensi administrasi. Kedua, kecenderungan untuk homogenitas (etnis, bahasa, agama, urban rural, dan tingkat pendapatan). Ketiga, adanya kemanjaan fiskal yang dijamin oleh UndangUndang baik dari segi dana alokasi umum, bagi hasil, dan pendapatan asli daerah. Terakhir, motif politik ekonomi para elit lokal dan pusat. ${ }^{5}$

Sedangkan menurut Fitria Fitrani, Bert Hofman, dan Kai Kaiser dalam Jurnal Bulletin Of Indonesia Economic Studies dengan judul Unity In Diversity? The Creation Of New Local Goverments In A Decentralising Indonesia menjelaskan konsep pemekaran muncul didasarkan oleh faktor sosial, faktor ekonomi, dan faktor politik. Faktor sosial berkorelasi dengan mendapatkan efektivitas pelayanan, faktor ekonomi adalah keinginan untuk mendapatkan suntikan dana, dan faktor politik berkaitan dengan ada pihak elite yang diuntungkan. Sehingga dalam melakukan pemekaran bukan hanya dinilai dari segi faktor di atas, melainkan adanya beberapa pertimbangan sesuai persyaratan secara teknis, kewilayahan, dan administratif. ${ }^{6}$

Selanjutnya, Menurut Blane D Lewis (2001) dalam buku yang berjudul The New Indonesian Equalization Transfer menjelaskan diterapkannya konsep desentralisasi sejak era reformasi, tidak dapat dipungkiri bahwa keinginan untuk melakukan pemekaran daerah dipicu oleh aspek keuangan daerah dan politis. Adanya asas desentralisasi akan memudahkan daerah dalam mengatur sumber daya yang dimiliki dan lebih maksimal dalam pengolahannya tentu untuk meningkatkan pendapatan keuangan daerah. ${ }^{7}$

Penelitian tentang pemekaran desa cukup menarik banyak perhatian ilmuwan seperti Nur Lailatul Mubarokah dengan judul Analisis Pemekaran Desa Terhadap Percepatan Pembangunan Infrastruktur (studi pada Desa Ringin Petuh Kecamatan Sampung Kabupaten Ponorogo), ${ }^{8}$ Budi Mulya \& Ulung Pribadi berjudul Analisis Persiapan Dalam Perencanaan Pemekaran di Desa Kabupaten Bulungan, ${ }^{9}$ dan Hanna Eko Puspita Sari dkk dengan judul Pemekaran Desa dalam Rangka Peningkatan Pelayanan Publik di Bidang Kesehatan Berkebutuhan Khusus. ${ }^{10}$

Gagasan pemekaran Nagari Persiapan Batahan Utara telah digagas sejak Tahun 2006. Salah satu alasan yang menguatkan nagari mekar akibat keadaan nagari yang sangat

\footnotetext{
${ }^{5}$ Tri Ratnawati. 2010. Satu Dasawarsa Pemekaran Daerah Era Reformasi: Kegagalan Otonomi Daerah?. Jurnal Ilmu Politik. 21(1): 124-125.

${ }^{6}$ Fitrani Fitria. 2005. Unity In Diversity? The Creation Of Local Goverments In A Decentralising Indonesia. Journal Bulletin Of Indonesia Economic Studies. 41(1): 64-66.

7 Joan Marta. 2012. Faktor Pemicu Penentu Kelayakan Pemekaran Wilayah Di Sumatera Barat (Pendekatan Sosial dan Ekonomi). Jurnal Ecosains. 1(1) 61-63.

${ }^{8}$ Nur Lailatul Barokah. 2018. Analisis Pemekaran Desa Terhadap Percepatan Pembangunan Infrastruktur (studi pada Desa Ringin Petuh Kecamatan Sampung Kabupaten Ponorogo). Hlm 3-10.

${ }^{9}$ Budi Mulya \& Ulung Pribadi. 2015. Analisis Persiapan Dalam Perencanaan Pemekaran Desa di Kabupaten Bulungan. Jurnal Ilmu Pemerintahan 2(1): 13-24

${ }^{10}$ Hannah Eko Puspita Sari dkk. 2018. Pemekaran Desa dalam Rangka Peningkatan Pelayanan Publik di Bidang Kesehatan Berkebutuhan Khusus. Jurnal Administrasi 1(2): 327-333
} 
memprihatinkan. Gagasan untuk mekar seakan tidak kunjung terlaksana akibat adanya kendala dalam regulasi moratorium pemekaran desa sesuai dengan Edaran Surat Menteri nomor 140/418/PMD Tanggal 13 Januari 2012 yang ditindaklanjuti dengan surat Gubernur Sumater Barat nomor 140/563/Pem-2012 tanggal 13 April 2012. ${ }^{11}$

Sebagai daerah yang mempunyai luas wilayah kurang lebih $3.887,77 \mathrm{Km}$, terdiri dari 11 kecamatan, dan memiliki 16 nagari induk disertai kepadatan penduduk menjadi salah satu alasan diperlukan adanya pemekaran nagari. Dalam memenuhi kebutuhan masyarakat, maka pemerintah daerah perlu atas suntikan dana. Namun, apabila berkaca terhadap nagari di Kabupaten Pasaman Barat pada tahun 2018, Alokasi Dana Nagari (ADN) dan Alokasi Dana Desa (ADD) hanya sekitar 102,6 Milyar yang dialokasikan terhadap 16 nagari. $^{12}$

Meskipun dengan komplikasinya dalam berbagai sektor tidak menjadi perhatian besar bagi sebagian Pemerintah Nagari Batahan. Ironisnya, Walinagari Batahan yang menjabat pada Periode Tahun 2014-2019 menolak untuk memekarkan Nagari Persiapan Batahan Utara akibat merasa akan dirugikan dalam hal pemasukan dana akan sedikit nantinya ke Nagari Batahan. Selain itu, kendala yang menjadikan Nagari Persiapan Batahan Utara lama berbenah akibat pertentangan penetapan batas wilayah. Masyarakat merasa dirugikan dengan adanya sebagian pembagian tanah yang digabungkan dengan nagari persiapan yang lain seperti Jorong Lubuk Gobing yang digabung dengan Nagari Persiapan Batahan Tengah, padahal dalam silsilah adat bahwa tanah tersebut milik Nagari Persiapan Batahan Utara.

Kelebihan dalam penelitian ini adalah Nagari Persiapan Batahan Utara telah mengupayakan mekar sejak Tahun 2006 dan baru terealisasikan Tahun 2016. Melihat dari rentang waktu yang lama untuk proses mekar, maka dalam penelitian ini akan menjelaskan sejauhmana proses yang dilalui untuk pengupayaan pemekaran dan apa saja faktor yang melatarbelakangi Nagari Persiapan Batahan Utara melakukan pemekaran. Faktor yang akan difokuskan dari segi sosial, ekonomi, dan politik.

Berdasarkan uraian diatas, kemudian peneliti rumuskan dalam pertanyaan penelitian yaitu: Apakah faktor yang melatarbelakangi proses pemekaran Nagari Persiapan Batahan Utara Kecamatan Ranah Batahan Kabupaten Pasaman Barat melakukan pemekaran sejak Tahun 2006?

\section{METODE PENELITIAN}

Penelitian tentang Analisis Faktor Pemekaran Nagari Persiapan Batahan Utara Kecamatan Ranah Batahan Kabupaten Pasaman Barat menggunakan pendekatan kualitatif, karena tujuan dari penelitian ini untuk mengetahui sejauhmana proses pemekaran nagari telah dilakukan serta faktor apa saja yang mempengaruhi dalam proses pemekaran nagari tersebut. Jenis penelitian yang digunakan adalah studi kasus intrinsik. Peneliti memilih studi kasus

11 Yusuf Asyari. 2018. Pemekaran Dikebut, Sumbar Punya 117 Nagari Persiapan diakses dari Https://www.jawapos.com diakses pada Tanggal 2 Juli 2021 pukul 08:00 WIB.

${ }^{12}$ Data Administratif Sekretaris Walinagari Batahan Tahun 2019. 
intrinsik karena dalam penelitian ini menarik untuk diteliti melihat dari fakta dan dokumen kenagarian Persiapan Batahan Utara menjelaskan, Nagari Persiapan Utara melakukan pemekaran telah digagas sejak Tahun 2006, namun baru terealisasikan pada Tahun 2016. Melihat dari proses masa pemekaran yang cukup lama di implikasikan bahwa pemicu pemekaran didasarkan atas keinginan untuk mendapatkan transfer dana desa yang lebih yang tujuannya melakukan penataan terhadap kualitas pelayanan dan infrastruktur yang lebih baik.

\section{HASIL DAN PEMBAHASAN}

Pemekaran merupakan proses perubahan wilayah menjadi sub-unit baru dengan tujuan mengupayakan kesejahteraan masyarakat. Konsep pemekaran digemari oleh setiap wilayah terutama nagari atau desa akibat komplikasi wilayah yang luas yang hampir sama komposisi kecamatan. Persoalan selanjutnya adalah pembagian dana yang diberikan tidak memadai akibat dari proporsi jorong yang dinaungi dalam nagari hampir sama dengan 1 (satu) desa. Awalnya, nagari di Pasaman Barat hanya berjumlah 16 nagari, setelah dilakukan pemekaran pada Tahun 2016 akhirnya jumlah nagari meningkat menjadi 71 Nagari Persiapan.

\section{Proses Pemekaran Nagari}

Proses Pemekaran Batahan Persiapan Batahan Utara mempunyai sejumlah tahapan yang panjang untuk dilalui. Proses pemekaran yang dilalui oleh nagari yang ada di Nagari Persiapan Batahan seakan tidak mudah untuk dilalui. Meskipun keinginan masyarakat Nagari Persiapan Batahan Utara untuk mekar sejak Tahun 2006, belum tentu langsung diterima begitu saja. Diperlukan adanya semacam landasan untuk membuat sub unit baru, sesuai dengan arahan dari Pemerintah Daerah Kabupaten Pasaman Barat.

Kegiatan dalam melakukan pemekaran nagari dibawa oleh pasangan Syahiran dan Yulianto pada saat Pilkada 2016. Salah satu tujuan yang ingin dicapai adalah mengentaskan Pasaman Barat dari ketertinggalan dengan jalan meningkatkan pendapatan dana desa yang akan diterima oleh masing-masing nagari dengan upaya pemekaran nagari. Lahirnya konsep pemekaran tidak selalu berjalan dengan baik, melainkan banyak kendala yang ditemukan bahkan berujung terhadap persengketaan pembagian batas wilayah.

Proses awal dimulai dari lamanya penyeragaman persepsi yang menunggu waktu lama akibat adanya penolakan dari Walinagari Batahan sendiri. Persoalan yang menjadikan Walinagari Batahan menolak pemekaran akibat adanya salah satu persyaratan dari jumlah penduduk yang masih kurang dari persyaratan, selain itu apabila nagari mekar maka akan mengurangi pemasukan dana. Pemenuhan persyaratan pemekaran Nagari Batahan melalui proses yang panjang. Dimulai dari tim panitia turun ke masyarakat untuk mengukur luas wilayah, jumlah penduduk, dan persyaratan lainnya. Jangka waktu yang diberikan hanya sekitar 2 mingguan, sehingga menambah tugas pemerintah nagari untuk membantu mempercepat penyelesaian persyaratan. Setelah rampung, maka syarat pemekaran Nagari 
Batahan diberikan kepada Pemda Kabupaten Pasaman Barat yang ditujukan untuk Kemendagri.

Ada tiga problema yang mengikuti lamanya proses terealisasikan pemekaran: pertama, adanya kendala dalam regulasi yaitu moratorium pemekaran nagari sesuai dengan Edaran Surat Menteri nomor 140/418/PMD Tanggal 13 Januari 2012 yang ditindaklanjuti dengan surat Gubernur Sumater Barat nomor 140/563/Pem-2012 tanggal 13 April 2012. Pembatasan regulasi seakan menjadi suatu penghalang bagi Nagari Persiapan Batahan Utara untuk mempercepat proses pemekaran.

Kedua, proses penyeragaman persepsi mendapatkan sebagian penolakan dan pemenuhan persyaratan yang rumit. Penolakan atas pemekaran nagari oleh Walinagari Batahan yaitu Salamat Riadi karena prosedur persyaratan pemekaran berkaitan dengan jumlah penduduk yang kurang serta apabila nagari mekar maka akan mengurangi pemasukan ke dana nagari. Namun, apabila pemerintah daerah sendiri tetap berusaha untuk mengupayakan pemekaran, maka segala kendala awal yang menyulitkan akan dapat diselesaikan dengan percepatan proses pemekaran.

Ketiga, dalam proses pemenuhan persyaratan mengalami kendala akibat peta wilayah yang tidak jelas, dikarenakan pembagian batas wilayah yang tidak valid. Pembagian batas wilayah menjadi salah satu tugas berat bagi panitia pemekaran. Dominasi masyarakat yang merasa dirugikan akibat pembagian tanah nagari yang tidak sesuai. Namun, setelah dilakukan peninjauan ulang, maka permasalahan batas wilayah sudah diselesaikan dan sudah ditetapkan dengan peta wilayah yang baru.

\section{Faktor Pemekaran Nagari}

Menurut dari Fitria Fitrani, Bert Hofman, dan Kai Kaiser faktor yang mendorong pemekaran terdiri dari: faktor sosial, faktor ekonomi, dan faktor politik. ${ }^{13}$

\section{Faktor Sosial}

Faktor sosial merupakan salah satu point utama penentu atas upaya pemekaran. Faktor sosial muncul disebabkan oleh kualitas pelayanan yang kurang baik akibat dari wilayah yang luas, kepadatan penduduk, sarana prasarana yang belum memadai serta kualitas dari sumber daya masyarakat yang kurang berdaya saing. Melihat dari segi pemekaran Nagari Persiapan Batahan Utara sendiri, upaya pemekaran nagari dilakukan akibat wilayah yang luas \pm 9.026 Ha menjadikan ongkos jalan untuk melakukan pelayanan ke nagari induk sangat mahal.

Perbandingan jarak yang ditempuh dari Nagari Persiapan Batahan Utara menuju Nagari Batahan $\pm 10 \mathrm{Km}$, meskipun jarak yang diperkirakan tidak jauh, namun apabila ditempuh bahkan mencapai waktu \pm 2 jam perjalanan. Tidak efisiennya waktu perjalanan,

\footnotetext{
${ }^{13}$ Ummy Athahirah, Astika dan Rossy Lambelanova. 2019. Kesiapan Pemekaran "Kabupaten Renah Indojati" di Provinsi Sumatera Barat. Jurnal Ilmu-Ilmu Sosial dan Humaniora. 21 (1): 60-63.
} 
sudah membuat masyarakat malas datang ditambah lagi dengan tingkat keamanan yang rendah menuju pusat pelayanan di Nagari Batahan, bukan hanya itu dalam manapaki jalan menuju pusat pelayanan yang menggunakan ojek dengan biaya Rp. 50.000/ 1 individu.

Selanjutnya, pemekaran nagari semakin digemari akibat kualitas dari infrastruktur jalan yang tidak diperbaiki. Pembangunan jalan tentunya memiliki jangka waktu untuk terus diperbaiki, alias adanya garansi perbaikan secara berlanjut. Akses jaringan jalan di Nagari Persiapan Batahan Utara masih didominasi oleh material tanah $7 \mathrm{~km}$ dan kerikil $8 \mathrm{~km}$. Jaringan jalan yang masih tanah dan kerikil membuat jarak tempuh perjalanan yang lama dan apabila cuaca hujan, maka akses menuju lokasi pelayanan akan sulit dicapai.

Sulit akses untuk menjangkau ke tempat pelayanan akibat perhatian yang diberikan oleh pemerintah nagari induk yang kurang. Perhatian untuk memberika kualitas infrastruktur yang kurang seperti perbaikan jalan menjadi problema bagi masyarakat, sehingga akses untuk melakukan pelayanan tidak efektif dilakukan. Akses kendaran yang bisa melewati jalan tanah hanya kendaran motor roda dua, sehingga dalam melakukan pelayanan diperlukan orang yang ahli dalam berkendara untuk mengantarkan ke tempat layanan di Nagari Batahan.

Point kepadatan penduduk juga menjadi salah satu pemicu atas pemekaran Nagari Persiapan Batahan Utara. Selayaknya pelayanan akan berjalan dengan baik, ketika pemakai jasa dari pelayanan yang dilayani sesuai dengan kapasitas layanan yang ditetapkan. Frekuensi jumlah penduduk menjadi salah satu pemicu sering terjadinya pelayanan yang kurang berkualitas. Bahkan, apabila pelayanan yang diberikan tetap tidak mengalami perbaikan, maka akan menimbulkan permasalahan yang akan memperumit tugas nagari.

\section{Faktor Ekonomi}

Faktor ekonomi dijadikan masyarakat sebagai kunci untuk menjaga keberlangsungan kehidupan. Ketergantungan terhadap siklus ekonomi menjadi tolak ukur penataan terhadap pembangunan. Setiap tahunnya penyaluran dana desa terus mengalami peningkatan, dan tergantung terhadap penggunaan kebutuhan masyarakat. Pada Tahun 2015-2019 anggaran dana desa mencapai Rp.257 triliun. Akibat dengan terus bergulirnya dana desa yang diberikan oleh pemerintah pusat, menjadi sarana bagi desa atau nagari untuk terus melakukan pemekaran. Ruang pemekaran dijadikan sebagai alat daerah dalam melakukan pembangunan nagari. Inilah strategi yang dibangun oleh pemerintah daerah dengan memekarkan nagari sesuai dengan proporsi yang diinginkan. Korelasinya dengan penelitian ini upaya mekar yang dilakukan oleh Nagari Persiapan Batahan Utara yaitu mendapatkan dana desa yang lebih. Selanjutnya, dana desa yang pernah masuk dalam kas Nagari Batahan sebagai berikut: 
Tabel 1. Jumlah Dana Desa Nagari Batahan Tahun 2015-2019

\begin{tabular}{ccc}
\hline No & \multicolumn{1}{c}{ Tahun } \\
\hline 1. & 2015 & Jumlah dana \\
2. & 2016 & Rp. $1,832,532.60$ \\
3. & 2017 & Rp. $1,458,517,744$ \\
4. & 2018 & Rp. $1,381,708,800$ \\
5. & 2019 & Rp. $3,078,948,000$ \\
Sumber : Data sekunder diolah oleh peneliti dari profil Nagari Persiapan Batahan Utara \\
\multicolumn{4}{c}{ Tahun 2020 }
\end{tabular}

Berdasarkan gambaran dana desa yang pernah diterima oleh Nagari Batahan, bahwa setiap tahunnya jumlahnya terus mengalami peningkatan. Meskipun jumlah dana desa yang diberikan terus naik, belum tentu bisa menjamin seluruh kebutuhan dari masyarakatnya. Setidaknya, jumlah jorong yang ada di Nagari Batahan sebanyak 26 (dua puluh enam), dan setiap jorong memiliki jumlah penduduk yang beragam. Misalnya saja Nagari Persiapan Batahan Utara yang terdiri dari 7 (tujuh) jorong, apabila jumlah dana desa yang diberikan hanya sekitar 100 (seratus) juta, belum tentu bisa untuk mencukupi dan umumnya untuk penggunaan dana desa mesti mempertimbangkan skala prioritas terutama dalam pembangunan.

Semakin kuatnya dorongan atas pemekaran nagari akibat dari Lemahnya perekonomian disebabkan oleh akses yang dibuka untuk masuk kawasan Nagari Persiapan Bataha Utara kurang memadai, kas dari nagari itu sendiri yang sedikit disebabkan oleh hasil pendapatan asli nagari (PAN) yang bisa dikatakan kosong. Pemasukan pendapatan asli Nagari Batahan tidak ada akibat BUMNag yang tidak berjalan dan sektor lain yang tidak dimanfaatkan dengan semestinya. Adanya eksploitasi terus-menerus yang dilakukan oleh pihak swasta untuk keuntungan sekelompok orang.

\section{Faktor Politik}

Pada umumnya keinginan untuk mekar di Nagari Batahan dilandaskan atas keinginan dari seluruh pihak terutama masyarakat dan pemerintah. Pada umumnya keinginan untuk mekar di Nagari Batahan dilandaskan atas keinginan dari seluruh pihak terutama masyarakat dan pemerintah. Kendati demikian, dalam suatu lingkup yang besar, tidak dapat dipungkiri akan ada munculnya upaya penolakan. Penjaminan terhadap keterlibatan aktor belum seutuhnya akan mendukung adanya pemekaran nagari. Walinagari Batahan sendiri selaku panitia yang mengurusi pemekaran Nagari Batahan menolak adanya upaya mekar.

Berploriferasinya nagari menjadi sub unit-unit baru, maka akan membuka peluang terhadap bertambahnya kelembagaan baru. Pemekaran nagari juga bertujuan untuk menambah penyerapan tenaga kerja. Penyerapan ketenagakerjaan dilakukan agar tingkat pengangguran yang terjadi di tingkat nagari menjadi menurun dalam grafiknya. Spesifikasi terhadap penerimaan pekerja yang bertugas untuk mengabdi dalam kelembagaan nagari tentu 
memiliki sejumlah persyaratan yang telah ditentukan oleh pemerintah daerah dan nagari. Jadi, bisa dikatakan bahwa penyerapan atas pekerja baru di nagari akan semakin bertambah.

\section{KESIMPULAN}

Peneliti berkesimpulan bahwa Hasil Pemekaran Nagari Persiapan Batahan Utara sejak Tahun 2006 dan baru terlaksana Tahun 2016 akibat dari adanya kendala dalam regulasi yaitu kendala dalam regulasi moratorium pemekaran desa sesuai dengan Edaran Surat Menteri nomor 140/418/PMD Tanggal 13 Januari 2012 yang ditindaklanjuti dengan surat Gubernur Sumater Barat nomor 140/563/Pem-2012 tanggal 13 April 2012, penolakan pemekaran yang muncul dari Walinagari Batahan periode Tahun 2015-2019, serta penetapan batas wilayah yang tidak kunjung tuntas. Meskipun beragam permasalahan muncul, tidak menjadikan masyarakat dan pemerintah untuk berdiam diri. Ada beberapa faktor yang menguatkan Nagari Persiapan Batahan Utara mekar yaitu:

Faktor sosial muncul akibat jarak tempuh pelayanan yang dilalui untuk sampai ke Nagari Batahan $\pm 10 \mathrm{Km}$ dengan waktu tempuh 2 jam, dengan rentang waktu yang lama akibat medan yang dilalui sulit, menjadikan ongkos pelayanan menjadi mahal dengan bayaran RP. 50.000/orang. Lama jarak tempuh yang dilalui diakibatkan oleh jaringan jalan mendominasi adalah tanah. Lokasi yang berada dalam kawasan hutan lindung dengan luas \pm 5.128 Ha dan persebaran penduduk yang tidak merata menimbulkan rasa keamanan terancam untuk melakukan pelayanan ke nagari induk. Kinerja dari pihak pemberi jasa layanan juga belum efektif akibat sarana-prasarana pelayanan belum memadai.

Faktor ekonomi juga menjadi pemicu perlunya pemekaran di Nagari Persiapan Batahan Utara. Dana desa yang diterima Nagari Batahan Tahun 2016 sekitar Rp. 1,130,517,744. Dana desa yang berjumlah Rp. 1,130,517,744 dan diberikan kepada 26 jorong dengan proporsi jumlah penduduk yang padat menjadikan persoalan yang sangat pelik. Selain itu, Pendapatan Asli Nagari Batahan (PAN) yang tidak berdaya menjadikan pemasukan ke kas nagari menjadi kosong. Selain suntikan dana desa, maka pihak pemerintah daerah Kabupaten Pasaman Barat juga memberikan dana dari 10\% APBD, namun itu belum mencukupi untuk memenuhi kebutuhan masyarakat. Sumber daya alam (SDA) yang ada di Nagari Persiapan Batahan Utara berkembang di sektor sawit dengan penghasilan 15 ton/bulan. Namun, segala bentuk kekayaan yang dimiliki dikuasai oleh pihak swasta dan terus menerus melilit masyarakat dalam lingkaran kemiskinan.

Faktor politik menjadi suatu arena untuk mempertaruhkan upaya pendefenitifan Pemekaran nagari Persiapan Batahan Utara. Kebijakan politik berupa pemekaran perlu disiasati dengan bantuan elite politik baik tingkat nagari maupun pihak daerah. Tujuan dengaa adanya wilayah administrasi baru akan membuka peluang untuk mengisi jabatan di kelembagaan baru. Masyarakat nagari yang semula lebih mencari kerja di luar nagari, akan terserap kembali dengan adanya lowongan kerja baru dan itu dibutuhkan untuk melakukan penataan nagari. 


\section{DAFTAR PUSTAKA}

Budi Mulya \& Ulung Pribadi. 2015. Analisis Persiapan Dalam Perencanaan Pemekaran Desa di Kabupaten Bulungan. Jurnal Ilmu Pemerintahan 2(1): 13-24.

Budi Mulyadi \& Ulung Pribadi. 2015. Analisis Persiapan Dalam Perencanaan Pemekaran Desa di Kabupaten Bulungan. Jurnal Ilmu Pemerintahan dan Kebijakan Publik. hlm. 6.

Fitrani Fitria. 2005. Unity In Diversity? The Creation Of Local Goverments In A Decentralising Indonesia. Journal Bulletin Of Indonesia Economic Studies. 41(1): 6466.

Hannah Eko Puspita Sari dkk. 2018. Pemekaran Desa dalam Rangka Peningkatan Pelayanan Publik di Bidang Kesehatan Berkebutuhan Khusus. Jurnal Administrasi 1(2): 327333.

Joan Marta. 2012. Faktor Pemicu Penentu Kelayakan Pemekaran Wilayah Di Sumatera Barat (Pendekatan Sosial dan Ekonomi). Jurnal Ecosains. 1(1) 61-63.

Nur Lailatul Barokah. 2018. Analisis Pemekaran Desa Terhadap Percepatan Pembangunan Infrastruktur (studi pada Desa Ringin Petuh Kecamatan Sampung Kabupaten Ponorogo). Hlm 3-10.

Peraturan Menteri Dalam Negeri Pemerintah Indonesia No.1 Tahun 2017 tentang Penataan Desa.

Siregar, Doli D. 2004. Manajemen Aset. Jakarta: Gramedia Pustaka Utama, hlm 255.

Tri Ratnawati. 2010. Satu Dasawarsa Pemekaran Daerah Era Reformasi: Kegagalan Otonomi Daerah?. Jurnal Ilmu Politik. 21(1): 124-125.

Ummy Athahirah, Astika dan Rossy Lambelanova. 2019. Kesiapan Pemekaran "Kabupaten Ranah Indojati" di Provinsi Sumatera Barat. Jurnal Ilmu-Ilmu Sosial dan Humaniora. 21 (1): 60-63. 